\title{
EVALUASI KUALITAS ARGUMEN PADA ARTIKEL JURNAL
}

\author{
Zain Syaifudin Nakrowi ${ }^{1}$ dan Yeti Mulyati ${ }^{2}$ \\ Universitas Hein Namotemo ${ }^{1}$ dan Universitas Pendidikan Indonesia ${ }^{2}$ \\ e-mail: zainsyaifudin@unhena.ac.id
}

\begin{abstract}
Abstrak
Argumentasi sangat penting dalam artikel ilmiah.Oleh karena itu, penelitian ini bertujuan mengungkap kualitas argumentasi dalam artikel ilmiah pada jurnal dengan scopependidikan bahasa Indonesia. Kualitas jurnal akan dievaluasi berdasarkan perspektif Toulmin. Evaluasi dipaparkan dalam pembagian kualitas argumentasi, struktur varian yang tampak dalam paragraf argumentasi, dan peringkat kualitas argumentasi pada jurnal terindeks sinta 2 sampai 6 . Untuk mengungkap kualitas argumen tersebut, peneliti menggunakan pendekatan mixed method. Hasil temuan dari penelitian ini, pertama: secara umum kualitas argumen dalam artikel yang berfokus pada pendidikan bahasa Indonesia masih rendah. Argumen secara dominan disajikan dengan struktur P-D.Kedua, terdapat empat varian struktur argumen yang ditemukan, yaitu: P-D, P-D-J, P-D-T, dan P-D-J-T. Ketiga, kualitas argumen berdasarkan nilai rerata konversi menunjukkan jurnal terakreditasi sinta 2 memiliki kualitas masuk pada klasifikasi sedang. Sementara artikel pada jurnal terakreditasi 3, 4, 5, 6 dan tidak terakreditasi memiliki kualitas argumen tergolong pada kategori rendah.
\end{abstract}

Kata kunci: kualitas argumen, wacana, perspektif toulmin

\section{EVALUATING THE QUALITY ARGUMENT IN JOURNAL ARTICLES}

\begin{abstract}
Arguments are very important in scientific articles. This study aims to reveal the quality of arguments in scientific articles in journals with the scope of Indonesian language education. The quality of the journal will be evaluated based on the Toulmin's perspective. Evaluation is described in the division of argumentation quality, variant structure that appears in the argumentation paragraphs, and argumentation quality ratings in indexed journals 2 to 6 . To reveal the quality of the arguments, the researcher uses a mixed method approach. The findings of this study are as follows. First: in general, the quality of the arguments in articles that focus on Indonesian language education is still low. The argument is predominantly presented with a P-D structure. Second, there are four variants of the argument structure found, namely: P-D, P-D-J, P-D-T, and P-D$\mathrm{J}-\mathrm{T}$. Third, the quality of the argument based on the average conversion value shows that the Sinta 2 accredited journals have medium classification. Meanwhile, articles in accredited journals 3, 4, 5, 6 and un-accredited have the quality of their arguments in the low category.
\end{abstract}

Keywords: quality of arguments, discourse, Toulmin's perspective 


\section{PENDAHULUAN}

Menulis merupakan usaha untuk mencapai kekekalan (Toer, 1990). Oleh karena itu, kegiatan menulis dinilai sangat penting bagi manusia. Di samping itu, menulis dipandang bukan hanya sebagai sarana komunikasi melainkan sebagai alat epistemologi dalam bidang akademik (McDermott \& Hand, 2010). Bahkan menulis dianggap sebagai kegiatan yang berdampak secara generatif terhadap progres pengetahuan (Preiss et al., 2013). Oleh karena itu, kegiatan menulis menjadi seksi untuk dibahas.

Salah satu jenis tulisan yang perlu diperhatikan yaitu argumentasi. Tulisan argumentatif tidak hanya dibutuhkan untuk kepentingan akademik, melainkan juga pada dunia kerja yang multikultural seperti saat ini (Allagui, 2019). Hal itu senada dengan yang disampaikan oleh Knudson (1994) bahwa argumentasi merupakan genre yang penting pada kehidupan bermasyarakat. Beberapa penelitian mengungkapkan alternatif untuk meningkatkan kemampuan menulis argumentatif (Berland \& Reiser, 2011; Sampson \& Clark, 2011; Hewings et al., 2010; Lam et al., 2018; Kathpalia $\&$ See, 2016).

Berjamurnya upaya peningkatan kemampuan menulis argumentatif menjadi bukti bahwa selain penting, keterampilan menulis argumentasi juga dinilai sebagai hal yang tidak mudah. Menulis argumentasi dianggap sulit karena dibutuhkan kemampuan kognitif dan linguistik yang bagus (Nippold \& Ward-Lonergan, 2010). Bukan hanya itu, ciri khas tulisan argumentasi yaitu klaim dan pembuktian atas klaim juga menjadi persoalan bagi penulis (Abdollahzadeh et al., 2017; Rusfandi, 2015). Artinya, masih banyak paragraf argumentasi yang memiliki kualitas yang rendah. Hal ini banyak ditemui juga dalam artikel di jurnal ilmiah.

Artikel ilmiah wajib memperkuat kualitas argumen. Selain digunakan untuk meyakinkan pembaca (Moeliono, 2004), argumen juga dapat meningkatkan kualitas kohesivitas tulisan (Kathpalia \& See, 2016). Oleh karena itu, penting untuk memperbanyak data dan referensi untuk menyusun argumentasi yang baik. Hal ini karena, argumentasi bukan hanya pendapat(klaim), tetapijuga menyertakan bukti dan jaminan teori.

Tulisan yang mengandung klaim yang bagus tanpa disertai alasan yang kuat, hanya akan menjadi tulisan sederhana (Stapleton \& Wu, 2015). Hal tersebut juga berlaku pada artikel jurnal ilmiah yang mengandung teks argumentasi. Oleh karena itu, untuk menjembatani antara klaim dan dukungan alasan penulis perlu mempertimbangkan kerangka TAP (Toulmin Argumentation Pattern) (Toulmin, 2003; Toulmin, 2012) yaitu: claim, grounds, warrants, backing, modal qualifiers, dan possible rebuttals. Sementara Simon (2008) berpandangan bahwa warrants dan backing menjadi bagian dari grounds. Selanjutnya peneliti mengusulkan unsur argumentasi diadaptasi dari perspektif Toulmin $(2003 ; 2012)$ terdiri atas claim atau pernyataan posisi $(\mathrm{P})$, ground atau data (D), warran dan backing masuk dalam bagian jaminan (J), modal qualifiers atau penegasan pernyataan posisi (T), dan possible rebuttals atau kemungkinan bantahan (B). 
Model TAP masif digunakan pertimbangan dalam membedah struktur argumentasi. Struktur tersebut selanjutnya dimanfaatkan untuk mengukur kualitas argumentasi (Qin \& Karabacak, 2010; Preiss et al., 2013; Setyaningsih, 2016). Meskipun telah banyak diungkap mengenai kualitas argumentasi berdasarkan perspektif Toulmin, tetapi hasilnya belum pernah digunakan dalam lintas peringkat (akreditasi) jurnal sebagai penerbit. Komparasi kualitas argumentasi pada artikel di setiap kategori/kelas akreditasi jurnal nasional akan diungkap dan menjadi kebaruan dari penelitian ini.

\section{METODE}

Penelitian ini menggunakan pendekatan mixed method dengan desain eksploratoris sekuensial kual-kuan (Creswell, 2013). Penggunaan metode kuantitatif hanya untuk membantu mengetahui perbandingan kualitas argumentasi pada artikel jurnal di setiap kategori/kelas akreditasi. Sumber data pada penelitian ini adalah paragraf argumentasi pada artikel jurnal. Paragraf yang dianalisis adalah bagian pembahasan. Bagian pembahasan menjadi penting untuk dianalisis agar dapat meningkatkan partisipasi akademik penulis (Setyaningsih, 2016). Adapun artikel yang dianalisis adalah tulisan yang berfokus pembelajaran bahasa Indonesia. Artikel yang dijadikan sampel penelitian berjumlah 6 (enam). 6 (enam) artikel itu diambil dari jurnal yang memiliki peringkat akreditasi sinta yang berbeda. Artikel tersebut dipilih dari jurnal nasional tidak terakreditasi sampai jurnal nasional terakreditasi sinta 2 .

Prosedur penelitian diawali dengan menyusun instrumen, kegiatan pengumpulan data, dan diakhiri dengan validasi data. Instrumen penelitian diadaptasi dari teori Toulmin (2003; 2012). Berikut ini intrumen penelitian yang digunakan untuk mengungkap kualitas argumentasi pada karya ilmiah.

Tabel 1. Nilai Argumentasi Berdasarkan Struktur

\begin{tabular}{lc}
\hline \multicolumn{1}{c}{ Struktur Argumentasi } & Nilai \\
\hline $\mathrm{P}$ - disertai satu jenis elemen pembuktian (D/T/J/B) & 1 \\
$\mathrm{P}$ - disertai dua jenis elemen pembuktian (D-J/D-T/D-B/J-T/J-B/T-B) & 2 \\
$\mathrm{P}$ - disertai tiga jenis elemen pembuktian (D-J-T/D-T-B) & 3 \\
$\mathrm{P}$ - disertai empat jenis elemen pembuktian (D-J-T-P) & 4 \\
\hline
\end{tabular}

Tabel 2. Konversi Rerata Nilai Struktur

\begin{tabular}{cc}
\hline Rerata Nilai & Kategori \\
\hline $1,00-1,59$ & Rendah \\
$1,60-2,59$ & Sedang \\
$2,60-3,59$ & Tinggi \\
$3,60-4.00$ & Sangat Tinggi \\
\hline
\end{tabular}


Tabel 3. Nilai Argumentasi Berdasarkan Struktur

\begin{tabular}{lc}
\hline \multicolumn{1}{c}{ Struktur Argumentasi } & Kategori \\
\hline $\begin{array}{l}\text { Didominasi oleh munculnya struktur P - disertai satu } \\
\text { jenis elemen pembuktian (D/T/J/B) }\end{array}$ & Rendah \\
$\begin{array}{l}\text { Didominasi oleh munculnya struktur P - disertai dua } \\
\text { jenis elemen pembuktian (D-J/D-T/D-B/J-T/J-B/T-B) } \\
\text { Didominasi oleh munculnya struktur P - disertai tiga } \\
\text { jenis elemen pembuktian (D-J-T/D-T-B) }\end{array}$ & Sedang \\
$\begin{array}{l}\text { Didominasi oleh munculnya struktur P - disertai empat } \\
\text { jenis elemen pembuktian (D-J-T-P) }\end{array}$ & Tinggi \\
\hline
\end{tabular}

Tabel 4. Penjelasan Elemen Argumentasi

\begin{tabular}{ll}
\hline \multicolumn{1}{c}{ Elemen } & \multicolumn{1}{c}{ Definisi } \\
\hline $\begin{array}{l}\text { Pernyataan Posisi (P) } \\
\text { Data (D) }\end{array}$ & $\begin{array}{l}\text { Gagasan berupa sikap penulis yang mendasari argumentasi. } \\
\text { Fakta berupa gambaran, fenomena, statistik, ilustrasi yang mendukung } \\
\text { pernyataan posisi. }\end{array}$ \\
Jaminan (J) & $\begin{array}{l}\text { Penguatan data berupa teori dan hasil penelitian relevan untuk } \\
\text { mendukung data yang disampaikan. }\end{array}$ \\
Penegasan Pernyataan & $\begin{array}{l}\text { Penekanan kembali pernyataan posisi argumentasi penulis untuk lebih } \\
\text { Pempengaruhi pembaca. }\end{array}$ \\
Kemungkinan Bantahan & $\begin{array}{l}\text { Kemungkinan bantahan (B) hadir bukan untuk melemahkan pernyataan } \\
\text { posisi (P), melainkan untuk memperkuat. Kemungkinan bantahan (B) } \\
\text { (B) }\end{array}$ \\
& $\begin{array}{l}\text { berisi pengecualian terhadap pernyataan posisi yang telah disampaikan. } \\
\text { pemikiran pembaca. }\end{array}$ \\
\hline
\end{tabular}

Selain intrumen mengukur kualitas argumentasi, penelitian ini juga menggunakan konversi presentase munculnya struktur. Hal ini untuk mempermudah penilaian secara kualitatif dari hasil konversi nilai kuantitatif. Berikut ini tabel pedoman konversi yang digunakan.

\section{Tabel 5. Konversi Presentase Kemunculan} Struktur Argumentasi

\begin{tabular}{cc}
\hline $\begin{array}{c}\text { Presentase } \\
\text { (dalam \%) }\end{array}$ & Kategori \\
\hline $0-25$ & Rendah \\
$26-50$ & Sedang \\
$51-75$ & Tinggi \\
$76-100$ & Sangat Tinggi \\
\hline
\end{tabular}

Selain intrumen yang digunakan dalam penelitian, bagian metode juga disajikan teknik pengumpulan data. Pengumpulan data kualitatif dilakukan dengan teknik simak (membaca) dan catat (Sudaryanto, 2015). Pengumpulan data kuantitatif dilakukan dengan cara mengobservasi hasil analisis data pada tahap pertama (kualitatif).

Validitas data dalam penelitian ini dilakukan dengan menggunakan triangulasi teori (Denzin \& Lincoln, 2011). Sebelum dilakukan analisis data, data yang sudah dikumpulkan divalidasi menggunakan pelbagai macam teori mengenai konsep dan hakikat paragraf 
argumentasi. Hal ini dilakukan untuk menguji dan memastikan data tersebut benar-benar masuk dalam paragraf argumentasi. Setelah divalidasi, data akan dianalisis dengan tahap pengumpulan dan pengkodean, pemaparan temuan, dan diakhiri dengan penarikan simpulan (Miles, 1994).

\section{HASIL DAN PEMBAHASAN \\ Hasil}

Berdasarkan variasi struktur argumentasi artikel pada jurnal yang fokus pada pembelajaran bahasa Indonesia terdapat empat varian. Empat varian struktur tersebut yaitu: P-D, P-D-J, P-D-T, dan P-D-J-T. Berikut ini variasi struktur dan presentase argumentasi yang peneliti temukan.
Setelah varian struktur argumentasi artikel yang sudah ditemukan, selanjutnya dilakukan konversi nilai. Langkah konversi ini ditempuh untuk mengetahui kualitas argumentasi masing-masing artikel. Temuan penelitian ini yakni artikel jurnal terakreditasi sinta 2 memiliki berada dalam kategori sedang, sedangkan artikel yang lain berada dalam kategori rendah. Berikut sajian data dalam bentuk diagram.

Temuan lain mengungkapkan bahwa struktur P-D merupakan struktur yang paling dominan dari seluruh artikel yang diteliti. Struktur P-D bahkan masuk dalam kategori sangat tinggi, jika dinilai dari presentasi kemunculannya. Berikut ini sajian data hasil penelitian.

Tabel 6. Varian Struktur Argumentasi Artike1

\begin{tabular}{cll}
\hline No & Peringkat Sinta & Struktur Argumentasi \\
\hline 1 & Sinta 2 & P-D, P-D-T, P-D-J-T \\
2 & Sinta 3 & P-D, P-D-T, P-D-J-T \\
3 & Sinta 4 & P-D, P-D-T \\
4 & Sinta 5 & P-D, P-D-J, P-D-J-T \\
5 & Sinta 6 & P-D \\
6 & Belum terakreditasi & P-D \\
\hline
\end{tabular}

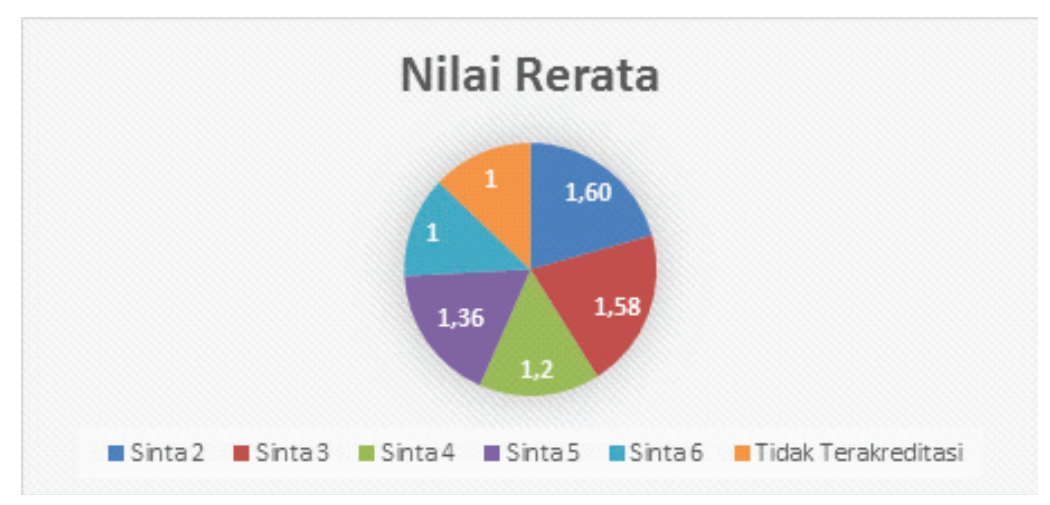

Gambar 1. Nilai Rerata Struktur Argumen 
Tabel 7. Presentase Munculnya Struktur Argumentasi

\begin{tabular}{ccccccc}
\hline \multirow{2}{*}{ No } & Klasifikasi Jurnal & $\begin{array}{c}\text { Jumlah Argumentasi } \\
\text { pada Bagian }\end{array}$ & \multicolumn{3}{c}{ Presentase munculnya struktur (\%) } \\
\cline { 3 - 7 } Pembahasan & P-D & P-D-T & P-D-J & P-D-J-T \\
\hline 1 & Terakreditasi Sinta 2 & 10 & 60 & 10 & 10 & 20 \\
2 & Terakreditasi Sinta 3 & 26 & 53.8 & 15.4 & 19.2 & 11.6 \\
3 & Terakreditasi Sinta 4 & 5 & 80 & 20 & 0 & 0 \\
4 & Terakreditasi Sinta 5 & 11 & 72.7 & 9.1 & 9.1 & 9.1 \\
5 & Terakreditasi Sinta 6 & 14 & 100 & 0 & 0 & 0 \\
6 & Tidak Terakreditasi & 8 & 100 & 0 & 0 & 0 \\
& Jumlah & 74 & $\mathbf{7 7 . 8}$ & 9.1 & 6.4 & 6.8 \\
\hline
\end{tabular}

\section{Pembahasan}

\section{Kualitas Argumentasi Berdasarkan Struktur Dominan}

Struktur argumentasi digunakan untuk mengungkap kualitas argumentasi yang disampaikan pada bagian pembahasan di artikel jurnal. Semakin kompleks elemennya, akan semakin tinggi tingkat argumentasinya (Ardianto, 2015). Oleh karena itu, penting untuk menampilkan analisis struktur argumentasi pada artikel ilmiah dalam setiap jenjang akreditasi. Berikut ini analisis varian struktur argumentasi dari pada artikel ilmiah dalam setiap jenjang akreditasi.

Tabel 8. Artikel Jurnal Sinta 2

\begin{tabular}{|c|c|c|c|c|}
\hline No & Sumber Artikel & Komponen Argumentasi & & Struktur \\
\hline \multirow[t]{5}{*}{1} & \multirow{5}{*}{$\begin{array}{l}\text { Bagian pembahasan, sub- } \\
\text { subbab pertama, paragraf } \\
\text { kedua. } \\
\text { Retorika: Jurnal Bahasa, } \\
\text { Sastra, dan Pengajarannya, } \\
\text { 12(2), 188-196. }\end{array}$} & Kalimat pertama & $\mathrm{P}$ & \multirow{5}{*}{ P-D } \\
\hline & & Kalimat kedua & $\mathrm{P}$ & \\
\hline & & Kalimat ketiga & $\begin{array}{l}\text { Bukan unsur } \\
\text { argumen (kalimat } \\
\text { tanya) }\end{array}$ & \\
\hline & & Kalimat keempat & $\mathrm{D}$ & \\
\hline & & Kalimat kelima & $\mathrm{D}$ & \\
\hline \multirow[t]{6}{*}{2} & \multirow{6}{*}{$\begin{array}{l}\text { Bagian pembahasan, sub- } \\
\text { subbab kedua, paragraf } \\
\text { ketiga. } \\
\text { Retorika: Jurnal Bahasa, } \\
\text { Sastra, dan Pengajarannya, } \\
\text { 12(2), 188-196. }\end{array}$} & Kalimat pertama & $\mathrm{P}$ & \multirow{6}{*}{ P-D-J-T } \\
\hline & & Kalimat kedua & $\mathrm{D}$ & \\
\hline & & Kalimat ketiga & $\mathrm{D}$ & \\
\hline & & Kalimat keempat & $\mathrm{D}$ & \\
\hline & & Kalimat kelima & $\mathrm{P}$ & \\
\hline & & Kalimat keenam & T-J & \\
\hline \multirow[t]{4}{*}{3} & \multirow{4}{*}{$\begin{array}{l}\text { Bagian pembahasan, sub- } \\
\text { subbab kedua, paragraf } \\
\text { kelima. } \\
\text { Retorika: Jurnal Bahasa, } \\
\text { Sastra, dan Pengajarannya, } \\
\text { 12(2), 188-196. }\end{array}$} & Kalimat pertama & $\mathrm{P}$ & \multirow{4}{*}{ P-D-T } \\
\hline & & Kalimat kedua & $\mathrm{D}$ & \\
\hline & & Kalimat ketiga & $\mathrm{T}$ & \\
\hline & & Kalimat keempat & $\overline{\mathrm{T}}$ & \\
\hline
\end{tabular}


Tabel 9 Jurnal Sinta 3

\begin{tabular}{|c|c|c|c|c|}
\hline No & Sumber Artikel & \multicolumn{2}{|c|}{ Komponen Argumentasi } & Struktur \\
\hline \multirow[t]{5}{*}{1} & \multirow{5}{*}{$\begin{array}{l}\text { Bagian hasil dan pembahasan, sub-bab } \\
\text { pertama, paragraf keempat } \\
\text { Jurnal Pendidikan Bahasa dan Sastra } \\
\text { Indonesia } \\
\text { Volume } 5 \text { Nomor } 1 \text { Maret 2020. Page 39-45 }\end{array}$} & Kalimat pertama & $\mathrm{P}$ & \multirow{5}{*}{ P-D-J-T } \\
\hline & & Kalimat kedua & $\mathrm{D}$ & \\
\hline & & Kalimat ketiga & $\mathrm{D}$ & \\
\hline & & Kalimat keempat & $\mathrm{D}$ & \\
\hline & & Kalimat kelima & T-J & \\
\hline \multirow[t]{4}{*}{2} & \multirow{4}{*}{$\begin{array}{l}\text { Bagian hasil dan pembahasan, sub-bab } \\
\text { kedua, paragraf ketiga } \\
\text { Jurnal Pendidikan Bahasa dan Sastra } \\
\text { Indonesia } \\
\text { Volume } 5 \text { Nomor } 1 \text { Maret 2020. Page 39-45 }\end{array}$} & Kalimat pertama & $\mathrm{P}$ & \multirow{4}{*}{ P-D } \\
\hline & & Kalimat kedua & $\mathrm{D}$ & \\
\hline & & Kalimat ketiga & $\mathrm{D}$ & \\
\hline & & & & \\
\hline \multirow[t]{4}{*}{3} & Bagian hasil dan pembahasan, sub-bab & Kalimat pertama & P-D & \multirow{4}{*}{ P-D-T } \\
\hline & ketiga, paragraf pertama & Kalimat kedua & $\mathrm{D}$ & \\
\hline & $\begin{array}{l}\text { Jurnal Pendidikan Bahasa dan Sastra } \\
\text { Indonesia }\end{array}$ & Kalimat ketiga & $\mathrm{T}$ & \\
\hline & Volume 5 Nomor 1 Maret 2020. Page 39-45 & & & \\
\hline
\end{tabular}

Tabel 10 Artikel Jurnal Sinta 4

\begin{tabular}{|c|c|c|c|c|}
\hline No & Sumber Artikel & Komponen Argu & & Struktur \\
\hline \multirow[t]{6}{*}{1} & \multirow{3}{*}{$\begin{array}{l}\text { Bagian hasil dan pembahasan, paragraf } \\
\text { pertama }\end{array}$} & Kalimat pertama & $\mathrm{P}$ & \multirow{6}{*}{ P-D } \\
\hline & & Kalimat kedua & $\mathrm{D}$ & \\
\hline & & Kalimat ketiga & $\bar{D}$ & \\
\hline & \multirow{3}{*}{$\begin{array}{l}\text { Diglosia - Jurnal Pendidikan, Kebahasaan, } \\
\text { dan Kesusastraan Indonesia } \\
\text { Vol. 3, No. 2, Agustus 2019, halaman 50-65 }\end{array}$} & Kalimat keempat & $\mathrm{D}$ & \\
\hline & & Kalimat kelima & $\mathrm{D}$ & \\
\hline & & Kalimat keenam & $\mathrm{D}$ & \\
\hline \multirow[t]{6}{*}{2} & \multirow{3}{*}{$\begin{array}{l}\text { Bagian hasil dan pembahasan, paragraf } \\
\text { keempat }\end{array}$} & Kalimat pertama & $\mathrm{P}$ & \multirow{6}{*}{ P-D-T } \\
\hline & & Kalimat kedua & $\mathrm{D}$ & \\
\hline & & Kalimat ketiga & $\mathrm{D}$ & \\
\hline & \multirow{3}{*}{$\begin{array}{l}\text { Diglosia - Jurnal Pendidikan, Kebahasaan, } \\
\text { dan Kesusastraan Indonesia } \\
\text { Vol. 3, No. 2, Agustus 2019, halaman 50-65 }\end{array}$} & Kalimat keempat & $\bar{D}$ & \\
\hline & & Kalimat kelima & $\mathrm{D}$ & \\
\hline & & Kalimat keenam & $\mathrm{T}$ & \\
\hline
\end{tabular}

Tabel 11 Artikel Jurnal Sinta 5

\begin{tabular}{lllll}
\hline No & Sumber Artikel & Komponen Argumentasi & Struktur \\
\hline 1 & $\begin{array}{l}\text { Bagian hasil dan pembahasan, paragraf } \\
\text { ketiga }\end{array}$ & Kalimat pertama & $\mathrm{P}$ & \\
\cline { 3 - 4 } & Kalimat kedua & $\mathrm{D}$ \\
\cline { 3 - 3 } & $\begin{array}{l}\text { Jurnal Pendidikan dan Pembelajaran Bahasa } \\
\text { Indonesia Vol 8 No 1, Maret 2019, halaman } \\
\text { 1-9 }\end{array}$ & Kalimat keempat & $\mathrm{D}$ \\
& & \\
\hline
\end{tabular}




\begin{tabular}{|c|c|c|c|c|}
\hline \multirow{2}{*}{$\frac{\text { No }}{2}$} & \multirow{3}{*}{$\begin{array}{l}\text { Sumber Artikel } \\
\text { Bagian hasil dan pembahasan, paragraf } \\
\text { keempat }\end{array}$} & \multicolumn{2}{|c|}{ Komponen Argumentasi } & \multirow[t]{2}{*}{ Struktur } \\
\hline & & Kalimat pertama & $\mathrm{P}$ & \\
\hline & & Kalimat kedua & $\mathrm{J}$ & \multirow{3}{*}{ P-D-J } \\
\hline & & Kalimat ketiga & $\mathrm{D}$ & \\
\hline & $\begin{array}{l}\text { Jurnal Pendidikan dan Pembelajaran Bahasa } \\
\text { Indonesia Vol } 8 \text { No 1, Maret 2019, halaman } \\
\text { 1-9 }\end{array}$ & & & \\
\hline \multirow[t]{9}{*}{3} & Bagian hasil dan pembahasan, paragraf & Kalimat pertama & $\mathrm{P}$ & \multirow{9}{*}{ P-D-J-T } \\
\hline & kesembilan belas & Kalimat kedua & $\mathrm{D}$ & \\
\hline & \multirow{7}{*}{$\begin{array}{l}\text { Jurnal Pendidikan dan Pembelajaran Bahasa } \\
\text { Indonesia Vol } 8 \text { No 1, Maret 2019, halaman } \\
\text { 1-9 }\end{array}$} & Kalimat ketiga & $\bar{D}$ & \\
\hline & & Kalimat keempat & $\bar{J}$ & \\
\hline & & Kalimat kelima & P-D & \\
\hline & & Kalimat keenam & $\mathrm{J}$ & \\
\hline & & Kalimat ketujuh & $\mathrm{J}$ & \\
\hline & & Kalimat kedelapan & $\mathrm{T}$ & \\
\hline & & Kalimat kesembilan & $\mathrm{T}$ & \\
\hline
\end{tabular}

Tabel 12 Artikel Jurnal Sinta 6

\begin{tabular}{lllll}
\hline No & Sumber Artikel & Komponen Argumentasi & Struktur \\
\hline 1 & $\begin{array}{l}\text { Bagian hasil dan pembahasan, Sub-bab } \\
\text { kedua, paragraf kelima }\end{array}$ & Kalimat pertama & P & \\
\cline { 3 - 4 } & & Kalimat kedua & $\mathrm{D}$ & \\
& & & P-D \\
& $\begin{array}{l}\text { Bahtera: Jurnal Pendidikan, Bahasa, Sastra, } \\
\text { dan Budaya, Jilid 07 / Nomor 1 / Maret } \\
\text { 2020, pp 765-781 }\end{array}$ & & \\
\hline
\end{tabular}

Tabel 13 Artikel Jurnal Nasional Tidak Terakreditasi

\begin{tabular}{|c|c|c|c|c|}
\hline \multirow{3}{*}{$\frac{\text { No }}{1}$} & \multirow{3}{*}{$\begin{array}{l}\text { Sumber Artikel } \\
\text { Bagian pembahasan, Sub-bab kedua, } \\
\text { paragraf pertama }\end{array}$} & \multicolumn{2}{|c|}{ Komponen Argumentasi } & \multirow[t]{2}{*}{ Struktur } \\
\hline & & Kalimat pertama & $\mathrm{P}$ & \\
\hline & & Kalimat kedua & $\mathrm{D}$ & \multirow{6}{*}{ P-D } \\
\hline & & Kalimat ketiga & $\mathrm{D}$ & \\
\hline & $\begin{array}{l}\text { Bahtera Indonesia: } \\
\text { Jurnal Penelitian }\end{array}$ & \multirow[t]{4}{*}{ Kalimat keempat } & \multirow[t]{4}{*}{$\mathrm{D}$} & \\
\hline & $\begin{array}{l}\text { Jurnal Penelitian } \\
\text { Pendidikan }\end{array}$ & & & \\
\hline & Bahasa dan Sastra Indonesia, Vol. 4, No.2, & & & \\
\hline & Sep. 2019, halaman 82-95 & & & \\
\hline
\end{tabular}

Terdapat 3 (tiga) artikel pada jurnal ilmiah yang memiliki tiga varian struktur, yaitu artikel pada jurnal terindeks sinta 2 , 3, dan 5. Artikel jurnal terindeks sinta 4 memiliki 2 (dua) varian struktur argumentasi. Artikel jurnal terindeks sinta 6 dan belum terakreditasi hanya memiliki satu varian struktur 
argumentasi. Berdasarkan temuan ini, dapat dikatakan bahwa jumlah varian struktur argumentasi tidak selaras dengan level akreditasi jurnal. Artikel pada jurnal terindeks sinta 5 , memiliki varian yang lebih banyak dibandingkan artikel jurnal yang terindeks sinta 4 .

Dalam penyelidikan ini juga diungkapkan varian struktur argumentasi P-D merupakan struktur yang paling sering digunakan dalam menyampaikan argumentasi. Seluruh artikel yang dikaji menggunakan struktur P-D dalam menyatakan argumentasi. Dominasi struktur P-D juga tampak pada presentase kemunculannya. Hal ini dapat dilihat pada tabel 7. Pada tabel 7 terlihat secara keseluruhan struktur P-D mencapai $77.8 \%$.

Dilihat dari struktur dominan yang muncul, maka argumentasi pada artikelartikel ini masuk pada kategori rendah (tabel 3). Hal ini sejalan dengan temuan Abduh et al. (2019) bahkan menyatakan struktur P-D adalah yang paling rendah. Temuan ini diperkuat oleh pendapat Toulmin (2012) yang menyatakan struktur argumentasi dasar terdiri atas claim, ground, warran, dan backing, sedangkan argumentasi yang baik diperkuat oleh modal qualifiers dan possible rebuttals. Berdasarkan pendapat Toulmin (2012), artinya struktur P-D masih tergolong rendah kualitasnya.

Dominannya struktur P-D pada wacana argumentasi sangat nyata. Ini harus menjadi perhatian semua pihak. Porsi argumentasi dalam penilaian penentuan akreditasi jurnal harus diperhatikan. Untuk saat ini, berdasarkan panduan akreditasi jurnal ilmiah (Permenristekdikti, 2018) bobot maksimal argumentasi yang termuat dalam poin analisis dan sintesis hanya 5 (lima). Meskipun sudah mengalami kenaikan dari yang sebelumnya poin maksimal yaitu 3 (tiga) (Ditlitabmas, 2014). Namun hal ini masih dirasa kurang, bahkan masih kalah jika dibandingkan unsur kelembangaan penerbit.

Selain hal di atas, peneliti menemukan dalam bagian pembahasan masih rendah dalam hal penyampaian jaminan (J) (tabel 5). Dari keseluruhan argumentasi, kemunculan jaminan hanya 13.4\%. Jaminan (J) lazimnya merupakan pendapat pakar atau temuan dari hasil penelitian yang relevan. Temuan ini selaras dengan hasil penelitian Setyaningsih (2016) dan Abduh et al., (2019). Setyaningsih (2016) menemukan minimnya jaminan (J) dalam karya ilmiah di jurnal terakreditasi bidang ekonomi. Sementara Abduh et al., (2019) hanya menemukan 9 (sembilan) jaminan (J) dari 110 data argumentasi yang dianalisis dari teks eksposisi siswa SMA. Padahal dengan adanya jaminan, unsur subjektivitas dalam penyampaian argumentasi pada bagian pembahasan dapat direduksi (Toulmin, 2012; Setyaningsih, 2016; Abduh et al., 2019).

Temuan lain mengungkapkan bahwa dari segi jumlah struktur argumentasi, artikel pada jurnal terakreditasi sinta 2,3, 4, dan 5 lebih tinggi dibandingkan jurnal sinta 6 dan jurnal yang tidak terakreditasi. Hal ini sesuai dengan tabel temuan di atas, yaitu jurnal sinta 6 dan yang tidak terakreditasi argumennya 100\% berstruktur P-D. Dengan kapasitas sebagai jurnal ilmiah nasional tentu saja 
hal ini sangat mengkhawatirkan, karena tergolong yang paling dasar Toulmin (2012). Untuk memperbaiki hal tersebut, pengelola jurnal dapat memisahkan antara hasil dan pembahasan. Tujuan dari langkah tersebut, untuk mengurangi kerancuan pada saat menyampaikan hasil penelitian (result atau finding) dan pembahasan (discussion). Langkah ini juga yang dilakukan oleh jurnal terakreditasi sinta 2 (Retorika: Jurnal Bahasa, Sastra, dan Pengajarannya). Hendaknya pembahasan disampaikan dengan argumentasi yang baik dengan mengelaborasi hasil penelitian dengan membandingkan dengan teori atau temuan penelitian orang lain. Hal tersebut dengan sendirinya akan memunculkan jaminan (J), bukan hanya pernyataan posisi (P) dan data (D) saja.

\section{Kualitas Argumentasi Berdasarkan Konversi Nilai}

Selain berdasarkan jumlah struktur struktur pada setiap artikel, kualitas argumentasi juga dinilai dari perhitungan hasil konversi elemen yang muncul. Argumen dengan struktur yang lebih banyak memiliki kualitas yang lebih tinggi. Hasil penjumlahan akan dicari rerata nilai untuk mengklasifikasikan kualitas argumen. Hal ini dapat dilihat pada gambar 1 .

Pada gambar 1, terlihat hanya artikel pada jurnal terakreditasi sinta 2 yang berada dalam kategori sedang. Sementara artikel padajurnal yanglain menunjukkan berada dalam ketegori rendah. Hal ini tentu dikarenakan begitu tingginya presentase munculnya struktur struktur P-D saja dalam paragraf argumentasi. Struktur yang sangat sederhana nenunjukkan penulis tidak cukup kuat dalam mempertahankan pernyataan posisi yang dikemukakan. Menurut Sampson \& Clark (2008) kondisi semacam itu dinilai buruk dalam teks argumentasi. Ketidakmampuan pemertahanan pernyataan posisi akan menegaskan bahwa klaim tersebut hanya bersifat subjektif semata. Tentu hal ini akan mengurangi sifat keilmiahan dari artikel jurnal.

\section{Upaya Peningkatan Kualitas Argumentasi}

Masih rendahnya kualitas tulisan argumentasi pada karya ilmiah diperlukan pelatihan dan pembelajaran. Pelatihan dan pembelajaran memungkinkan terjadinya perbaikan kualitas teks argumentasi pada karya ilmiah. Hal ini dikarenakan menulis dipandang sebagai proses kognitif (Sibarani, 2015). Artinya, kegiatan menulis bukan sekadar jasmani (behavioral) semata, melainkan terdapat dorongan secara mental (Piaget, 1969). Dorongan sikap mental, pemikiran, rasional inilah yang mendasari bahwa proses belajar dan latihan perlu dilakukan sebagai pemantik. Selain itu, hasil beberapa penelitian juga menunjukkan terdapat perbaikan kualitas teks argumentasi setelah diberikan perlakuan.

Penelitian yang dilakukan oleh (Shinta \& Filia, 2020) menemukan bahwa pembelajaran kolaboratif mampu meningkatkan kualitas argumentasi siswa. Pembelajaran kolaboratif mampu menambah jumlah struktur argumentasi pada tulisan siswa. Selain itu, keterampilan berpikir siswa dalam proses pembelajaran juga meningkat. Temuan dalam penelitian ini menguatkan asumsi bahwa treatment berupa pembelajaran dapat mempengaruhi 
proses kognitif yang berujung pada peningkatan kualitias tulisan argumentasi.

Perlakuan tidak hanya dilakukan dengan penggunaan strategi belajar, tetapi juga dengan penggunaan media. Pada masa pandemi seperti saat ini, penggunaan media pembelajaran inovatif sangat penting dilakukan. Hal ini untuk menunjang keberhasilan pembelajaran jarak jauh. Setipe dengan pembelajaran, pelatihan menulis saat ini juga harus mengadaptasi kondisi pandemi. Pembelajaran dan pelatihan menulis dengan menggunakan media daring, berbasis web, berbantuan komputer harus sering dilakukan. Penelitian menunjukkan adanya dampak media pembelajaran dilakukan oleh Evmenova et al. (2016). Dalam penelitiannya Evmenova et al. (2016) menemukan penggunakan media Computer-Based Graphic Organizer (CBGO) dalam Self-Regulated Learning (SLR) secara kuantitas kalimat dan kualitas argumentasi secara holistik meningkat. Oleh karena itu, webinar dan pelatihan menulis daring dengan menggunakan media yang inovatif dirasa tepat sebagai wujud upaya peningkatan kualitas argumentasi dalam artikel ilmiah.

Pelaksanaan webinar dan pelatihan menulis daring, selain untuk melatih keterampilan menulis juga membuka wawasan. Wawasan mengenai konsep teori sebagai dasar rujukan dalam menulis argumentasi sangat diperlukan. Meskipun menurut (Kuhn, 2010) argumentasi tidak hanya berbentuk teori. Namun, teori tetap menjadi salah satu struktur penting dalam membangun kualitas argumentasi yang baik. Oleh karena itu, di samping membuka wawasan mengenai teori-teori baru, kegiatan webinar dan pelatihan menulis diharapkan dapat menambah keterampilan literasi informasi peserta. Literasi dan keterampilan berargumentasi sangat berkaitan (Lupton, 2008; Harianto et al., 2017). Keterampilan menjelajah, menemukan, mengaitkan, dan mengelaborasikan konsep teori dengan hasil penelitian tentu akan meningkatkan kualitas argumentasi.

\section{SIMPULAN}

Meskipun penelitian sebelumnya sudah banyak disampaikan mengenai evaluasi argumen menggunakan perspektif Toulmin, tetapi belum ada yang menggunakan data pada masingmasing jurnal dengan kelas (akreditasi) yang berbeda. Dengan demikian, temuan penelitian ini menjadi hal yang baru dalam mengungkap kualitas argumen dala artikel jurnal. Berdasarkan temuan dalam penelitian ini, peneliti menyimpulkan kualitas argumen pada semua jenjang akreditasi dari sinta 2-6 dan belum terakreditasi yang berfokus pada pendidikan bahasa Indonesia perlu ditingkatkan. Berdasarkan sampel yang diteliti menunjukkan dominasi P-D (rendah). Terlebih untuk jurnal dengan akreditasi rendah (sinta 6) dan belum terakreditasi, penyampaian argumentasi dalam bagian pembahasan hanya ada struktur P-D. Selain itu, penelitian ini juga menemukan bahwa jurnal yang berada di akreditasi sinta 2 memiliki kualitas argumentasi yang paling tinggi, jika dinilai dilihat dari rerata konversi nilai argumentasi, yaitu 1,60 atau tergolong pada tingkat sedang. Meskipun demikian, penelitian ini hanya mengungkap kualitas argumen berdasarkan jumlah struktur yang terdapat 
dalam wacana pembahasan. Penelitian selanjutnya diharapkan dapat menganalisis dari segi sifat struktur atau pada objek yang lain, misalkan pada latar belakang artikel.

\section{UCAPAN TERIMA KASIH}

Ucapan terima kasih ditujukan untuk Sekolah Pascasarjana UPI yang telah memberikan dorongan semangat demi terselesaikannya penelitian ini. Selain itu, peneliti juga menyampaikan ucapa terima kasih untuk reviewer yang memberikan masukan sangat berarti dalam perbaikan artikel ini, sehingga layak untuk dipublikasikan. Tidak lupa ungkapan terima kasih disampaikan pada penulis artikel yang karyanya dimanfaatkan sebagai data dalam penelitian ini.

\section{DAFTAR PUSTAKA}

Abdollahzadeh, E., Amini Farsani, M., \& Beikmohammadi, M. (2017). Argumentative Writing Behavior of Graduate EFL Learners. Argumentation. https://doi. org/10.1007/s10503-016-9415-5

Abduh, N. K., Sastromiharjo, A., \& Anshori, D. S. (2019). Struktur Argumentasi pada Genre Teks Eksposisi Karangan Siswa SMA. Retorika: Jurnal Bahasa, Sastra, Dan Pengajarannya, 11(1), 40-47. https:// doi.org/10.26858/retorika . v12i1.7372

Allagui, B. (2019). Writing a Descriptive Paragraph Using an Augmented Reality Application: An Evaluation of Students' Performance and Attitudes. Technology, Knowledge and
Learning. https://doi.org/10.1007/ s10758-019-09429-2

Ardianto, A. (2015). Struktur Argumen dalam Wacana Karya Tulis Ilmiah Mahasiswa. Litera Jurnal Penelitian Bahasa, Sastra, dan Pembelajarannnya. 14(1), 1-10. https://doi. org/10.21831/1tr.v14i1.4402

Berland, L. K., \& Reiser, B. J. (2011). Classroom Communities' Adaptations of the Practice Of Scientific Argumentation. Science Education. 95(2), 191-216. https:// doi.org/10.1002/sce. 20420

Creswell, J. (2013). Qualitative, Quantitative, and Mixed Methods Approaches. In Research design

Denzin, N. K., \& Lincoln, Y. (2011). Disciplining the Practice of Qualitative Research. In The SAGE Handbook of Qualitative Research.

Ditlitabmas, D. I. K. T. I. (2014). Pedoman Akreditasi Terbitan Berkala Ilmiah.

Evmenova, A. S., Regan, K., Boykin, A., Good, K., Hughes, M., MacVittie, N., Sacco, D., Ahn, S. Y., \& Chirinos, D. (2016). Emphasizing Planning for Essay Writing With a ComputerBased Graphic Organizer. Exceptional Children. 82(2). https://doi. org/10.1177/0014402915591697

Harianto, Y., Saefudin, \& Nuraeni, E. (2017). Analysis of Students' Quantitative Literacy in Human Coordination System Concept. International Journal of Science and Applied Science: Conference Series, 2(1), 440-447. https://doi.org/10.20961/ ijsascs.v2i1.16764

Hewings, A., Lillis, T., \& Vladimirou, D. (2010). Who's Citing Whose 
Writings? A Corpus Based Study of Citations as Interpersonal Resource in English Medium National and English Medium International Journals. Journal of English for Academic Purposes. 9(2), 102-115. https://doi.org/10.1016/j. jeap.2010.02.005

Kathpalia, S. S., \& See, E. K. (2016). Improving Argumentation Through Student Blogs. System. https://doi. org/10.1016/j.system.2016.03.002

Knudson, R. E. (1994). An Analysis of Persuasive Discourse: Learning How to Take a Stand. Discourse Processes, 18(2), 211-230. https://doi. org/10.1080/01638539409544892

Kuhn, D. (2010). Teaching and Learning Science as Argument. Science Education. 94(5), 910-824. https:// doi.org/10.1002/sce.20395

Lam, Y. W., Hew, K. F., \& Chiu, K. F. (2018). Improving Argumentative Writing: Effects of a Blended Learning Approach and Gamification. Language Learning and Technology.

Lupton, M. (2008). Evidence, Argument and Social Responsibility: First-Year Students' Experiences of Information Literacy when Researching an Essay. Higher Education Research and Development, 27(4), 399-414. https://doi. org/10.1080/07294360802406858

McDermott, M. A., \& Hand, B. (2010). A Secondary Reanalysis of Student Perceptions of Non-Traditional Writing Tasks Over a Ten Year Period. Journal of Research in Science
Teaching, 47(5), 518-539. https:// doi.org/10.1002/tea.20350

Miles, M. A. (1994). Miles and Huberman (1994)- Chapter 4.pdf. In Qualitative Data Analysis: An Expanded Sourcebook.

Moeliono, A. (2004). Pengajaran Bahasa Indonesia untuk Tujuan Akademis. Linguistik Indonesia (pp. 209-226).

Nippold, M. A., \& Ward-Lonergan, J. M. (2010). Argumentative Writing in Pre-Adolescents: The Role of Verbal Reasoning. Child Language Teaching and Therapy, 26(3), 238-248. $\mathrm{h} \mathrm{t} \mathrm{t} \mathrm{p} \mathrm{s}$ : / / $\mathrm{d}$ o $\mathrm{i}$. org/10.1177/0265659009349979

Permenristekdikti. (2018). Peraturan Menteri Riset, Teknologi dan Pendidikan Tinggi Nomor 9 Tahun 2018 Tentang Akreditasi Jurnal Ilmiah. In Direktorat Jenderal Penguatan Riset dan Pengembangan.

Piaget, J. (1969). The Psychology of the Child. New York: Basic Book

Preiss, D. D., Castillo, J. C., Flotts, P., \& San Martín, E. (2013). Assessment of Argumentative Writing and Critical Thinking in Higher Education: Educational Correlates and Gender Differences. Learning and Individual Differences. 28, 193203.https://doi.org/10.1016/j. lindif.2013.06.004

Qin, J., \& Karabacak, E. (2010). The Analysis of Toulmin Elements in Chinese EFL University Argumentative Writing. System, 38(3), 444-456. https://doi. org/10.1016/j.system.2010.06.012 
Rusfandi. (2015). ArgumentCounterargument Structure in Indonesian EFL Learners English Argumentative Essays: A Dialogic Concept of Writing. RELC Journal. 46(2), 1-17. https://doi. org/10.1177/0033688215587607

Sampson, V., \& Clark, D. B. (2008). Assessment of the Ways Students Generate Arguments in Science Education: Current Perspectives and Recommendations for Future Directions. Science Education, 92(3), 447-472. https://doi.org/10.1002/ sce. 20276

Sampson, V., \& Clark, D. B. (2011). A Comparison of the Collaborative Scientific Argumentation Practices of Two High and Two Low Performing Groups. Research in Science Education, 41(1), 63-97. https://doi.org/10.1007/s11165009-9146-9

Setyaningsih, Y. (2016). Struktur Argumen Paragraf Argumentatif pada Artikel Jurnal Terakreditasi Bidang Ekonomi (Perspektif Stephen Toulmin). Adabiyyāt: Jurnal Bahasa dan Sastra, 15(2), 136-156.. https:// doi.org/10.14421/ ajbs.2016.15202

Shinta, D. K., \& Filia, F. (2020). Improving Students' Arguments Through Collaborative Learning. Indonesian Journal of Applied Linguistics, 10(2), 349-358. https:// doi.org/10.17509/ijal.v10i2.28602

Sibarani, B. (2007). Penerapan Proses Kognitif dan erapi Cognitive
Blocking dalam Peningkatan Kualitas Pembelajaran Menulis. Diksi, 14(2), 132-142. DOI: $10.21831 /$ diksi.v14i2.6595

Simon, S. (2008). Using Toulmin's Argument Pattern in The Evaluation of Argumentation in School Science. International Journal of Research and Method in Education. 31(3), 277-289. $\mathrm{h} \mathrm{t} \mathrm{t} \mathrm{p} \mathrm{s}$ : / / d o i . org/10.1080/17437270802417176

Stapleton, P., \& Wu, Y. (Amy). (2015). Assessing the Quality of Arguments in Students' Persuasive Writing: a Case Study Analyzing the Relationship Between Surface Structure and Substance. Journal of English for Academic Purposes. 17:1223. https://doi.org/10.1016/j. jeap.2014.11.006

Sudaryanto, D. P. (2015). Metode dan Aneka Teknik Analisis Bahasa (Method and Technique of Language Study). In Sanata Dharma University Press.

Toer, P. A. (1990). Rumah Kaca. Wira Karya.

Toulmin, S. E. (2003). The Uses of Argument: Updated Edition. In The Uses of Argument: Updated Edition. https://doi.org/10.1017/ CBO9780511840005

Toulmin, S. E. (2012). The Layout of Arguments. In The Uses of Argument. https://doi.org/10.1017/ cbo9780511840005.007 


\section{Lampiran}

Tabel 1. Artikel Jurnal Sinta 2

\begin{tabular}{|c|c|c|c|c|}
\hline No & Sumber Artikel & Komponen Argumentasi & & Struktur \\
\hline \multirow[t]{5}{*}{1} & \multirow{5}{*}{$\begin{array}{l}\text { Bagian pembahasan, } \\
\text { sub- subbab } \\
\text { pertama, paragraf } \\
\text { kedua. } \\
\text { RETORIKA: Jurnal } \\
\text { Bahasa, Sastra, dan } \\
\text { Pengajarannya, } \\
\text { 12(2), 188-196. }\end{array}$} & $\begin{array}{l}\text { Kalimat pertama :'Bias gender yang dipaparkan } \\
\text { tersebut la-hir dari cara pandang penulis buku } \\
\text { teks." }\end{array}$ & $\mathrm{P}$ & \multirow{5}{*}{ P-D } \\
\hline & & $\begin{array}{l}\text { Kalimat kedua: "Salah satu faktor yang } \\
\text { mempengaruhi cara pandang penulis buku teks } \\
\text { yang bias gender adalah ling-kungan sosialnya." }\end{array}$ & $\mathrm{P}$ & \\
\hline & & Kalimat ketiga :"Mengapa demikian?" & $\begin{array}{l}\text { Bukan } \\
\text { unsur } \\
\text { argumen } \\
\text { (kalimat } \\
\text { tanya) } \\
\end{array}$ & \\
\hline & & $\begin{array}{l}\text { Kalimat keempat: "Hal ter-sebut dikarenakan } \\
\text { lingku-ngan sosial menjadi salah satu faktor yang } \\
\text { membentuk persepsi atau sudut pandang seseorang } \\
\text { terhadap lingkungan sekitarnya dan memengaruhi } \\
\text { seseorang merasa-kan atau menerima hal tersebut." }\end{array}$ & $\mathrm{D}$ & \\
\hline & & $\begin{array}{l}\text { Kalimat kelima: "Teks yang dihasilkan oleh penulis } \\
\text { tidak bisa lepas dari ling-kungan sosial penulis } \\
\text { buku teks tersebut." }\end{array}$ & $\mathrm{D}$ & \\
\hline \multirow[t]{6}{*}{2} & \multirow{6}{*}{$\begin{array}{l}\text { Bagian pembahasan, } \\
\text { sub- subbab kedua, } \\
\text { paragraf ketiga. } \\
\text { RETORIKA: Jurnal } \\
\text { Bahasa, Sastra, dan } \\
\text { Pengajarannya, } \\
\text { 12(2), 188-196. }\end{array}$} & $\begin{array}{l}\text { Kalimat pertama: "Frasa tersebut digunakan penulis } \\
\text { kepada pembaca untuk menyampaikan gagasannya } \\
\text { bah-wa selama ini perempuan identik sebagai } \\
\text { hadiah atau imbalan" }\end{array}$ & $\mathrm{P}$ & \multirow{6}{*}{ P-D-J-T } \\
\hline & & $\begin{array}{l}\text { Kalimat kedua: "Kata sebagai yang menerangkan } \\
\text { sesuatu yang sewajarnya atau sepatutnya akan } \\
\text { diterima oleh pembaca dan pembaca akan meng- } \\
\text { anggap hal tersebut sebagai hal yang lazim, lum- } \\
\text { rah atau biasa saja." }\end{array}$ & $\mathrm{D}$ & \\
\hline & & $\begin{array}{l}\text { Kalimat ketiga: "Penyapaan langsung, temuan } \\
\text { peneliti yaitu penulis menggunakan kata ganti } \\
\text { orang ketiga tunggal, kata ganti orang ketiga ja- } \\
\text { mak, dan kata ganti orang pertama tunggal untuk } \\
\text { menampilkan tokoh perempuan dalam teks." }\end{array}$ & $\mathrm{D}$ & \\
\hline & & $\begin{array}{l}\text { Kalimat keempat:" Kata ganti yang ditemukan, } \\
\text { yaitu kata ibu, istri, ia, dan putri." }\end{array}$ & $\mathrm{D}$ & \\
\hline & & $\begin{array}{l}\text { Kalimat kelima :"Penulis membawa pembaca } \\
\text { sebagai bagian yang tak terpisahkan dengan teks." }\end{array}$ & $\mathrm{P}$ & \\
\hline & & $\begin{array}{l}\text { Kalimat keenam: "Oleh karena itu, pembaca tidak } \\
\text { dianggap semata se-bagai pihak yang hanya } \\
\text { menerima teks, tetapi ju-ga ikut melakukan } \\
\text { transaksi sebagaimana yang terlihat dalam teks } \\
\text { (Mills dalam Eriyanto, 2003)." }\end{array}$ & T-J & \\
\hline
\end{tabular}

104 | LITERA, Volume 20, Nomor 1, Maret 2021 


\begin{tabular}{|c|c|c|c|c|}
\hline No & Sumber Artikel & Komponen Argumentasi & & Struktur \\
\hline \multirow[t]{4}{*}{3} & \multirow{4}{*}{$\begin{array}{l}\text { Bagian pembahasan, } \\
\text { sub- subbab kedua, } \\
\text { paragraf kelima. } \\
\text { RETORIKA: Jurnal } \\
\text { Bahasa, Sastra, dan } \\
\text { Pengajarannya, } \\
\text { 12(2), 188-196. }\end{array}$} & $\begin{array}{l}\text { Kalimat pertama: "Perlu dipahami bahwa buku teks } \\
\text { seba-gai sebuah medium pembelajaran, hadir } \\
\text { sebagai suatu wacana." }\end{array}$ & $\mathrm{P}$ & \multirow{4}{*}{ P-D-T } \\
\hline & & $\begin{array}{l}\text { Kalimat kedua: "Teks wacana merupakan suatu } \\
\text { praktik sosial karena mampu menggerakkan, } \\
\text { membatasi, membentuk, dan mengarahkan suatu } \\
\text { subjek dalam proses pembelajaran." }\end{array}$ & $\mathrm{D}$ & \\
\hline & & $\begin{array}{l}\text { Kalimat ketiga: "Oleh sebab itu, teks yang } \\
\text { digunakan di sekolah harus meru-pakan teks yang } \\
\text { adil gender." }\end{array}$ & $\mathrm{T}$ & \\
\hline & & $\begin{array}{l}\text { Kalimat Keempat: "Karena inilah guru, sekolah, } \\
\text { dan pemerintah harus selektif terhadap teks bacaan } \\
\text { yang digunakan." }\end{array}$ & $\mathrm{T}$ & \\
\hline
\end{tabular}

Tabel 2. Jurnal Sinta 3

\begin{tabular}{|c|c|c|c|c|}
\hline No & Sumber Artikel & Komponen Argumentasi & & Struktur \\
\hline \multirow[t]{5}{*}{1} & $\begin{array}{l}\text { Bagian hasil dan } \\
\text { pembahasan, sub- }\end{array}$ & $\begin{array}{l}\text { "Karakter menunjukkan bagaimana seseorang } \\
\text { bertingkah laku." }\end{array}$ & $\mathrm{P}$ & \multirow{5}{*}{ P-D-J-T } \\
\hline & $\begin{array}{l}\text { bab pertama, } \\
\text { paragraf keempat } \\
\text { Jurnal Pendidikan }\end{array}$ & $\begin{array}{l}\text { "Apabila seseorang berperilaku tidak jujur, kejam, } \\
\text { dan rakus, dapatlah dikatakan orang tersebut } \\
\text { memanifestasikan perilaku buruk." }\end{array}$ & $\bar{D}$ & \\
\hline & $\begin{array}{l}\text { Bahasa dan Sastra } \\
\text { Indonesia } \\
\text { Volume } 5 \text { Nomor } 1\end{array}$ & $\begin{array}{l}\text { "Sebaliknya, apabila seseorang berperilaku jujur, } \\
\text { bertanggung jawab, suka menolong, tentulah orang } \\
\text { tersebut memanifestasikan karakter mulia." }\end{array}$ & $\mathrm{D}$ & \\
\hline & $\begin{array}{l}\text { Maret 2020. Page 39- } \\
45\end{array}$ & $\begin{array}{l}\text { "Istilah karakter juga erat kaitannya dengan } \\
\text { personality. Seseorang baru dapat dikatakan "orang } \\
\text { yang berkarakter" (a person of character) apabila } \\
\text { tingkah lakunya sesuai dengan kaidah moral." }\end{array}$ & $\mathrm{D}$ & \\
\hline & & $\begin{array}{l}\text { "Dengan demikian, pendidikan karakter yang baik } \\
\text { harus melibatkan bukan saja aspek pengetahuan } \\
\text { yang baik (moral knowing), tetapi juga harus } \\
\text { merasakan dengan baik atau loving the good (moral } \\
\text { feeling), dan perilaku yang baik (moral action) } \\
\text { sebagaimana yang dinyatakan oleh Lickona } \\
\text { (1992:143) dalam gambar berikut ini. } \\
\text { " }\end{array}$ & T-J & \\
\hline
\end{tabular}

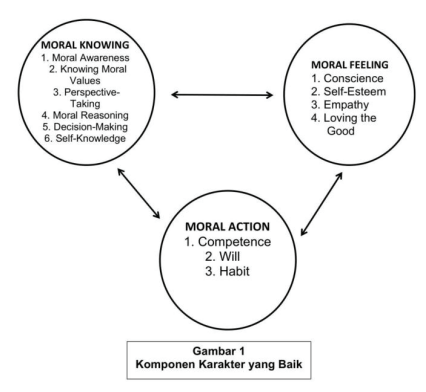




\begin{tabular}{|c|c|c|c|c|}
\hline No & Sumber Artikel & Komponen Argumentasi & & Struktur \\
\hline \multirow[t]{3}{*}{2} & $\begin{array}{l}\text { Bagian hasil dan } \\
\text { pembahasan, sub- } \\
\text { bab kedua, paragraf }\end{array}$ & $\begin{array}{l}\text { "Dalam kaitannya dengan pendidikan karakter, } \\
\text { prosedur pembelajaran menyimak ini merupakan } \\
\text { saluran pendidikan karakter." }\end{array}$ & $\bar{P}$ & \multirow{3}{*}{ P-D } \\
\hline & $\begin{array}{l}\text { ketiga } \\
\text { Jurnal Pendidikan } \\
\text { Bahasa dan Sastra }\end{array}$ & $\begin{array}{l}\text { "Pada masing-masing tahapan pembelajaran } \\
\text { menyimak akan terdapat sejumlah aktivitas yang } \\
\text { harus dilakukan siswa." }\end{array}$ & $\bar{D}$ & \\
\hline & $\begin{array}{l}\text { Indonesia } \\
\text { Volume } 5 \text { Nomor } 1 \\
\text { Maret 2020. Page } 39 \text { - } \\
45\end{array}$ & $\begin{array}{l}\text { "Melalui aktivitas-aktivitas inilah siswa akan secara } \\
\text { tidak sadar akan menunjukkan karakter dirinya." }\end{array}$ & $\mathrm{D}$ & \\
\hline \multirow[t]{3}{*}{3} & $\begin{array}{l}\text { Bagian hasil dan } \\
\text { pembahasan, sub- } \\
\text { bab ketiga, paragraf }\end{array}$ & $\begin{array}{l}\text { "Keterampilan berbicara menempati kedudukan } \\
\text { yang penting karena merupakan ciri kemampuan } \\
\text { komunikatif siswa." }\end{array}$ & P-D & \multirow{3}{*}{ P-D-T } \\
\hline & $\begin{array}{l}\text { Dertama } \\
\text { Jurnal Pendidikan } \\
\text { Bahasa dan Sastra } \\
\text { Indonesia }\end{array}$ & $\begin{array}{l}\text { "Dengan kata lain, kemampuan berbicara tidak } \\
\text { hanya berperan dalam pembelajaran bahasa tetapi } \\
\text { berperan penting pula dalam pembelajaran yang } \\
\text { lain." }\end{array}$ & $\mathrm{D}$ & \\
\hline & $\begin{array}{l}\text { Volume } 5 \text { Nomor } 1 \\
\text { Maret 2020. Page } 39 \text { - } \\
45\end{array}$ & $\begin{array}{l}\text { "Hal ini berarti salah satu indikator keberhasilan } \\
\text { siswa belajar adalah kemampuannya } \\
\text { mengungkapkan gagasannya secara lisan di dalam } \\
\text { kelas dalam satu lingkup mata pelajaran tertentu." }\end{array}$ & $\mathrm{T}$ & \\
\hline
\end{tabular}

Tabel 3. Artikel Jurnal Sinta 4

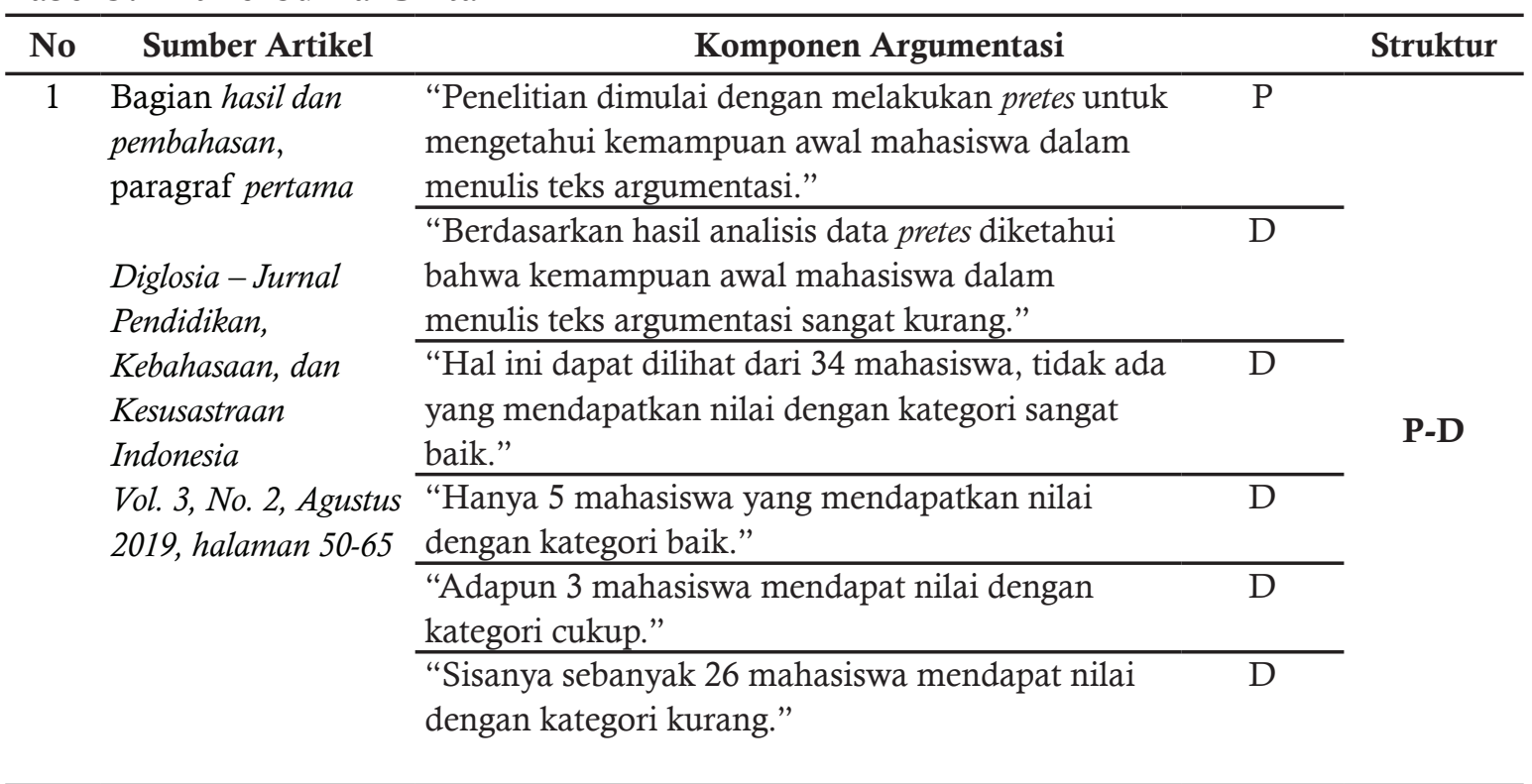




\begin{tabular}{|c|c|c|c|c|}
\hline No & Sumber Artikel & Komponen Argumentasi & & Struktur \\
\hline \multirow[t]{6}{*}{2} & $\begin{array}{l}\text { Bagian hasil dan } \\
\text { pembahasan, } \\
\text { paragraf keempat }\end{array}$ & $\begin{array}{l}\text { "Berdasarkan hasil analisis data posttest di atas } \\
\text { dapat diketahui bahwa terdapat peningkatan hasil } \\
\text { belajar mahasiswa dalam pembelajaran menulis } \\
\text { teks argumentasi." }\end{array}$ & $\mathrm{P}$ & \multirow{6}{*}{ P-D-T } \\
\hline & $\begin{array}{l}\text { Diglosia - Jurnal } \\
\text { Pendidikan, } \\
\text { Kebahasaan, dan } \\
\text { Kesusastraan }\end{array}$ & $\begin{array}{l}\text { "Hal ini dapat dilihat dari hasil posttest yang } \\
\text { menunjukkan bahwa dari } 34 \text { mahasiswa, } 4 \\
\text { mahasiswa mendapatkan nilai dengan kategori } \\
\text { sangat baik." }\end{array}$ & $\mathrm{D}$ & \\
\hline & $\begin{array}{l}\text { Indonesia } \\
\text { Vol. 3, No. 2, Agustus }\end{array}$ & $\begin{array}{l}\text { "Sebanyak } 11 \text { mahasiswa mendapatkan nilai } \\
\text { dengan kategori baik." }\end{array}$ & $\mathrm{D}$ & \\
\hline & 2019, halaman 50-65 & $\begin{array}{l}\text { "Adapun } 6 \text { mahasiswa mendapatkan nilai dengan } \\
\text { kategori cukup." }\end{array}$ & $\bar{D}$ & \\
\hline & & $\begin{array}{l}\text { "Sisanya sebanyak } 13 \text { mahasiswa mendapatkan } \\
\text { nilai dengan kategori kurang." }\end{array}$ & $\mathrm{D}$ & \\
\hline & & $\begin{array}{l}\text { "Oleh karena itu, dapat disimpulkan bahwa } \\
\text { metode Copy the master efektif untuk meningkatkan } \\
\text { hasil belajar mahasiswa dalam pembelajaran } \\
\text { menulis teks argumentasi." }\end{array}$ & $\mathrm{T}$ & \\
\hline
\end{tabular}

Tabel 4. Artikel Jurnal Sinta 5

\begin{tabular}{|c|c|c|c|c|}
\hline No & Sumber Artikel & Komponen Argumentasi & & Struktur \\
\hline \multirow[t]{9}{*}{1} & \multirow{2}{*}{$\begin{array}{l}\text { Bagian hasil dan } \\
\text { pembahasan, } \\
\text { paragraf ketiga }\end{array}$} & "Tataran frasa lebih tinggi daripada sekadar kata." & $\mathrm{P}$ & \multirow{9}{*}{ P-D } \\
\hline & & $\begin{array}{l}\text { "Frasa minimal memiliki dua kata yang berfungsi sebagai } \\
\text { unsur diterangkan (D) dan unsur menerangkan (M) hal } \\
\text { ini nampaknya juga berlaku pada bahasa daerah." }\end{array}$ & $\mathrm{D}$ & \\
\hline & \multirow{7}{*}{$\begin{array}{l}\text { Jurnal Pendidikan } \\
\text { dan Pembelajaran } \\
\text { Bahasa } \\
\text { Indonesia Vol } 8 \\
\text { No 1, Maret 2019, } \\
\text { halaman 1-9 }\end{array}$} & "Campur kode penyisian frasa bahasa daerah dalam kode & $\mathrm{D}$ & \\
\hline & & bahasa Indonesia terlihat pada tuturan penyaji II & & \\
\hline & & (DBIN1511) pada kata lare bhayai (Indonesia: anak bayi) & & \\
\hline & & yang merupakan bahasa Using jika dilihat dari loga & & \\
\hline & & pengucapan si penutur lare (anak) berfungsi sebagai unsur & & \\
\hline & & D dan bhayai (bayi)." & & \\
\hline & & $\begin{array}{l}\text { "Bentuk campur kode yang berupa penyisipan unsur- } \\
\text { unsur frasa juga terlihat." }\end{array}$ & $\overline{\mathrm{D}}$ & \\
\hline \multirow[t]{7}{*}{2} & \multirow[t]{2}{*}{$\begin{array}{l}\text { Bagian hasil dan } \\
\text { pembahasan, } \\
\text { paragraf keempat }\end{array}$} & $\begin{array}{l}\text { "Bentuk selanjutnya yang peneliti temukan dalam } \\
\text { tuturan mahasiswa Universitas PGRI Banyuwangi } \\
\text { adalah campur kode yang berbentuk baster." }\end{array}$ & $\mathrm{P}$ & \multirow{7}{*}{ P-D-J } \\
\hline & & "Baster merupakan hasil perpaduan dua unsur bahasa & $\mathrm{J}$ & \\
\hline & \multirow{5}{*}{$\begin{array}{l}\text { Jurnal Pendidikan } \\
\text { dan Pembelajaran } \\
\text { Bahasa } \\
\text { Indonesia Vol } 8 \\
\text { No 1, Maret 2019, } \\
\text { halaman 1-9 }\end{array}$} & $\begin{array}{l}\text { yang berbeda membentuk satu makna (Harimurti, 1993: } \\
\text { 92)." }\end{array}$ & & \\
\hline & & "Meskipun intensitas kemunculannya tidak terlalu sering, & $\overline{\mathrm{D}}$ & \\
\hline & & bentuk campur kode penyisipan unsur-unsur baster juga & & \\
\hline & & telihat ada beberapa percakapan mahasiswa di kelas." & & \\
\hline & & & & \\
\hline
\end{tabular}




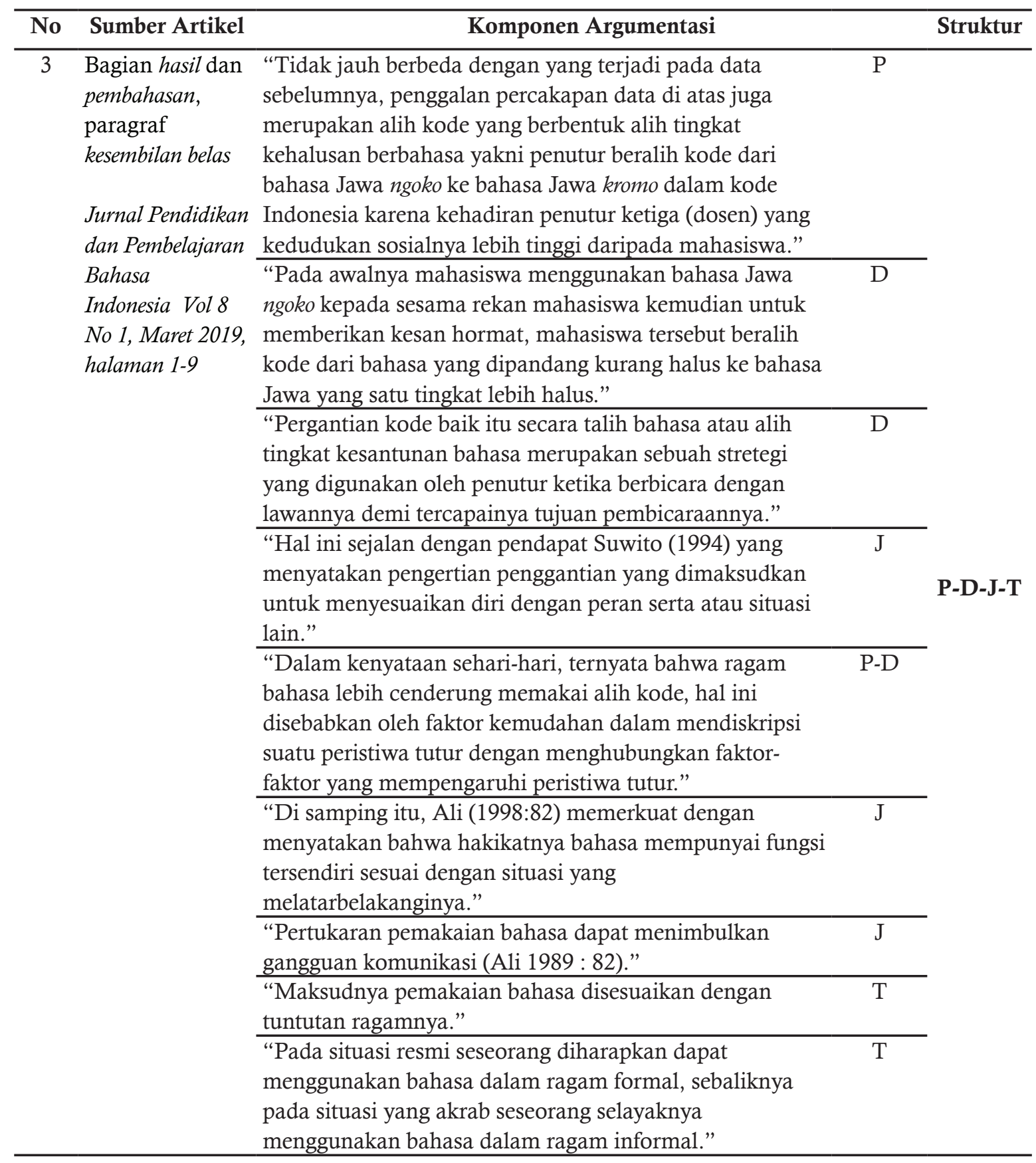

108 | LITERA, Volume 20, Nomor 1, Maret 2021 
Tabel 5. Artikel Jurnal Sinta 6

\begin{tabular}{|c|c|c|c|c|}
\hline No & Sumber Artikel & Komponen Argumentasi & & Struktur \\
\hline \multirow[t]{2}{*}{1} & $\begin{array}{l}\text { Bagian hasil dan } \\
\text { pembahasan, Sub-bab } \\
\text { kedua, paragraf } \\
\text { kelima }\end{array}$ & $\begin{array}{l}\text { "Kondisi kelas yang tergambar di atas harus segera } \\
\text { diberikan treatmen untuk meningkatkan } \\
\text { keterampilan siswa dalam menulis teks } \\
\text { eksplanasi." }\end{array}$ & $\mathrm{P}$ & \\
\hline & $\begin{array}{l}\text { Bahtera: Jurnal } \\
\text { Pendidikan, Bahasa, } \\
\text { Sastra, dan Budaya, } \\
\text { Jilid } 07 \text { / Nomor 1 / } \\
\text { Maret 2020, pp 765- } \\
781\end{array}$ & $\begin{array}{l}\text { "Pada kondisi ini, peneliti merancang memberikan } \\
\text { pembelajaran kolaborasi antara model dan media } \\
\text { pembelajaran." }\end{array}$ & $\mathrm{D}$ & P-D \\
\hline
\end{tabular}

Tabel 6. Artikel Jurnal Nasional Tidak Terakreditasi

\begin{tabular}{|c|c|c|c|c|}
\hline No & Sumber Artikel & Komponen Argumentasi & & Struktur \\
\hline \multirow[t]{6}{*}{1} & $\begin{array}{l}\text { Bagian pembahasan, } \\
\text { Sub-bab kedua, } \\
\text { paragraf pertama }\end{array}$ & $\begin{array}{l}\text { "Tabel di atas menunjukkan bahwa ketiga subjek } \\
\text { (S7, S9, dan S11) sudah dapat memperlihatkan } \\
\text { bentuk kreativitas berbahasanya." }\end{array}$ & $\mathrm{P}$ & \multirow{6}{*}{ P-D } \\
\hline & & "Hal ini ditunjukkan dengan mengubah bentuk & $\mathrm{D}$ & \\
\hline & $\begin{array}{l}\text { BAHTERA } \\
\text { INDONESIA: }\end{array}$ & $\begin{array}{l}\text { lirik lagu yang sebenarnya dengan kosakata lain, } \\
\text { misalnya Satu-satu aku sayang nenek, Dua-dua juga }\end{array}$ & & \\
\hline & Jurnal Penelitian & sayang kakak, Tiga tiga sayang saudaraku." & & \\
\hline & $\begin{array}{l}\text { Pendidikan } \\
\text { Bahasa dan Sastra }\end{array}$ & $\begin{array}{l}\text { "Begitupun ada yang menggantinya dengan Satu- } \\
\text { satu aku sayang Bunda Dua-dua juga sayang ayah." }\end{array}$ & $\mathrm{D}$ & \\
\hline & $\begin{array}{l}\text { Indonesia, Vol. 4, } \\
\text { No.2, Sep. 2019, } \\
\text { halaman 82-95 }\end{array}$ & $\begin{array}{l}\text { "Ada satu subjek yang berbeda dengan yang } \\
\text { lainnya, yakni dengan kreativitas berbahasanya } \\
\text { menjadi Satu-satu aku naik motor Dua-dua juga } \\
\text { naik mobil, Tiga-tiga naik beca, Satu, dua, tiga naik } \\
\text { kendaraan(S11)." }\end{array}$ & $\mathrm{D}$ & \\
\hline
\end{tabular}

